Research Article

\title{
Market Integration and Regional Innovation in China: Evidence from the Yangtze River Delta Region
}

\author{
Xiaohong Liu $\mathbb{D}^{1}$ and Ching-Ter Chang $\mathbb{D}^{2,3,4}$ \\ ${ }^{1}$ Business College, Nanjing Xiaozhuang University, Nanjing, China \\ ${ }^{2}$ Department of Information Management, Chang Gung University, Taoyuan, Taiwan \\ ${ }^{3}$ Clinical Trial Center, Chang Gung Memorial Hospital, Linkou, Taoyuan, Taiwan \\ ${ }^{4}$ Department of Industrial Engineering and Management, Ming Chi University of Technology, Taipei, Taiwan
}

Correspondence should be addressed to Xiaohong Liu; amylxhong@163.com

Received 7 September 2021; Accepted 13 October 2021; Published 31 October 2021

Academic Editor: Yong Aaron Tan

Copyright () 2021 Xiaohong Liu and Ching-Ter Chang. This is an open access article distributed under the Creative Commons Attribution License, which permits unrestricted use, distribution, and reproduction in any medium, provided the original work is properly cited.

\begin{abstract}
Market integration is an important tool for China's regionally coordinated economic development. At the same time, China is implementing an innovation-driven development strategy. Therefore, the way the market integration affects regional innovation is of great significance to analyze this problem. The panel data of 27 cities in the Yangtze River Delta region in China with the highest degree of economic integration from 2009 to 2018 are used to investigate the impact of market integration (MI) on regional innovation (RI). The main findings are as follows: the first-order lag term of RI is significantly positive, and RI has certain path dependence. In this regard, MI has a positive impact on RI and promotes RI. The estimated coefficient of MI is significantly positive and has a positive impact on RI and promotes RI. This provides a reference for promoting RI through MI. The contributions of the paper are threefold: (1) This paper examines the impact of MI on RI to provide policy implications for the coordinated development of innovation between regions. (2) The relative price method is adopted to measure the MI, which covers 16 kinds of commodities, covering a wider range than does the traditional method. (3) This paper uses the generalized method of moments (GMM) to test the effect of MI on RI for the first time.
\end{abstract}

\section{Introduction}

Innovation is crucial for economic development. Therefore, all countries spare no effort in innovation, and China is no exception. The Chinese government places great importance on innovation by widely implementing its innovation-driven development strategy to continuously enhance economic innovation and competitiveness. As the report of the Nineteenth National Congress pointed out, "Accelerate the construction of an innovative country. Innovation is the first driving force for development." The 2020 government work report states "Improve the support capacity of scientific and technological innovation. Stably support basic research and applied basic research, and guide enterprises to increase R\&D investment." At the same time, China, as the largest developing country in the world, is speeding up the implementation of its regionally coordinated development strategy.
China is strongly promoting the coordinated development of Beijing-Tianjin-Hebei and the integrated development of the Yangtze River Delta (YRD). The outline of the MI development plan for the YRD in December 2019 pointed out that regional development linkages should be strengthened, and cross-border regional construction and sharing should be promoted. The 2021 government work report also pointed out that China should optimize its regional economic layout and promote regional coordinated development, especially regarding the integrated development of the Yangtze River Delta. The report also proposed a vigorous promotion of scientific and technological innovation and adherence to innovation-driven development. Therefore, what is the impact of MI on RI? In the context of China's promotion of MI and improvement of technological innovation capabilities, studying this issue has important practical significance for China to build an innovative country. 
MI is also known as regional MI, which refers to the free flow of goods and elements between regions based on market signals. The hypothesis of MI and market segmentation is derived from arbitrage theory. Under the framework of the law of one price, when the level of integration among regions rises, the cost of commodity transportation and trade will decrease, and the price difference between regions will continue to shrink [1]. MI and market segmentation are opposing concepts. The level of MI is inversely proportional to market segmentation [2]. The earliest research on China's MI was conducted from the perspective of market segmentation [3-6].

Some studies have measured regional innovation. Hellwig et al. [7] proposed a structural microeconometric approach to measure the degree of market integration stemming from unilateral demand and supply shocks such as the generation of energy from volatile renewable resources, the unavailability of generation units, and national holidays. Gluschenko [8] found that the extent of dependence of regional prices on regional demand serves in measuring the degree of market integration.

Many studies have explored the environmental effects of MI. For example, Li and Lin [9] evaluated the $\mathrm{CO}_{2}$ levels of 28 provinces in China from 1995 to 2012 and investigated the impact of $\mathrm{MI}$ on $\mathrm{CO}_{2}$ levels. Their results show that $\mathrm{MI}$ can effectively reduce $\mathrm{CO}_{2}$ emissions. He et al. [10] used data from 30 Chinese provinces from 2002 to 2011 and found that MI has a significantly positive impact on the reduction of $\mathrm{CO}_{2}$ marginal cost. Shao et al. [11] used panel data from 1995 to 2014 in the Yangtze River Delta to investigate the relationship between market segmentation and $\mathrm{CO}_{2}$ emissions and found that there is a U-shaped relationship between the two. Zhang [12] asserted that MI will have a positive impact on environmental pollution because MI will increase the efficiency of factor allocation, form consistent environmental standards, and improve energy efficiency $[13,14]$. Bian et al. [15] used data from 31 Chinese provinces from 2002 to 2015 to investigate the relationship between MI and environmental pollution from the perspective of resource mismatch and concluded that market segmentation would aggravate the problem of environmental pollution. In addition, market segmentation will aggravate the mismatch of labor and capital resources, which will lead to environmental pollution. Uribe et al. [16] found that greater market integration permits a higher level of risk sharing between electricity markets and, as a result, can be expected to reduce the probability of energy crises and energy shortages occurring in any given market in Nord Pool. Zhang et al. [17] found that market integration in neighboring regions is conducive to reducing local pollution emissions. Harkening back to how coastal areas in China experienced economic opening, Su and Liang [18] proposed that coastal areas should increase their environmental total factor energy productivity by speeding up their MI. Hou and Song [19] found that market integration can help improve regional green total factor productivity.
The technology, talent flow, and technology spillovers of economic globalization affect the innovation level of individual countries and the innovation gap between them [20,21]. MI will also impact a country's RI. For example, Young [22] held that innovation incentives come from market incentives and the improvement of commodity MI can significantly improve innovation efficiency. Federico [23] found that the degree of MI could improve market efficiency and accelerate the transformation of innovation results. Sun et al. [24] used panel data from 29 Chinese provinces from 2004 to 2015 to analyze the impact of market segmentation on technological innovation and found that market segmentation hinders technological innovation.

The above studies have laid a foundation for this paper but also have some shortcomings. First, little attention has been devoted to understanding the impact of market integration on regional innovation. Moreover, while the existing studies analyze the influence of MI on RI at the provincial level, they lack discussion at the city level. Second, most of the measures of MI select only eight kinds of commodities and only match adjacent cities, which is not sufficiently comprehensive. Finally, the studies use the static panel model, which may have measurement errors and missing variables, leading to endogeneity problems, thus causing estimation bias.

The aim of this paper is to study the impact of market integration on regional innovation. Of the three major economic regions in China, the Pearl River Delta Economic Region, the Yangtze River Delta Economic Region, and the Bohai Bay Economic Region, the YRD region is the most developed. These three economic regions, the most developed in the country, are the lifeblood of China's economy. The YRD consists of the Shanghai, Jiangsu, and Zhejiang provinces, which include a total of 27 cities. The total GDP of the Yangtze River Delta urban area reached 20.5 trillion yuan in 2020, accounting for $20.18 \%$ of the country's GDP and ranking first among the three economic regions. Per capita GDP is also as high as $131,900 \mathrm{CNY}$, which is greater than that of the other two economic regions. In addition, the degree of economic integration in the YRD is relatively high. Therefore, based on panel data from the YRD from 2009 to 2018, this paper studies the impact of MI on RI, and the suggestions made can be used as a reference for regional economic development in China.

Specifically, this paper makes the following contributions. First, based on the perspective of cities, this paper examines the impact of MI on RI. This will shed light on the policy implications for the coordinated development of innovation between regions. Second, the relative price method, which covers all 16 types of commodities, is adopted to measure MI, thereby covering a wider range than does the traditional method. At the same time, pair matching between cities allows for a more comprehensive and accurate measurement of MI. Third, to control endogeneity problems, this paper uses the generalized method of moments (GMM) to test the effect of MI on RI for the first time. 


\section{Methodology and Data}

2.1. Econometric Model. Following Zhang et al. [17], this paper constructs the following econometric model:

$$
R I_{i t}=\alpha_{0}+\beta_{0} M I_{i t}+\sum \gamma_{j} x_{i j t}+\mu_{i}+\lambda_{t}+\varepsilon_{i t} .
$$

In the above formula, the subscript $i$ represents the city, the subscript $t$ represents the year, and RI is the regional innovation. MI is the core explanatory variable of this paper, representing market integration, and $x_{i j t}$ is the control variable, which will be introduced below. $\mu_{i}$ is an unobservable regional individual effect and $\lambda_{t}$ is a time effect. $\varepsilon_{i t}$ is a random disturbance term that follows a normal distribution, and $\mu_{i}$ is not relevant to $\varepsilon_{i t}$.

Equation (1) is a static panel model. There may be path dependence in RI. Based on this, the first-order lag of RI is added to equation (1) to control the dynamic effect of the model. The dynamic panel model is as follows:

$$
R I_{i t}=\alpha_{0}+\alpha_{1} R I_{i, t-1}+\beta_{0} M I_{i t}+\sum \gamma_{j} x_{i j t}+\mu_{i}+\lambda_{t}+\varepsilon_{i t},
$$

where $\mathrm{RI}_{\mathrm{i}, \mathrm{t}-\mathrm{1}}$ is the first-order lag of regional innovation.

2.2. Methodology. The GMM method begins by making a first-order difference on the estimation equation to remove the influence of fixed effects and then uses the lag variable of the explanatory variable as the estimation method of the difference variable to avoid the deviation caused by neglecting some necessary explanatory variables and control, to some extent, the endogeneity caused by bidirectional causality. The dynamic panel econometric model takes the dependent variable as the independent variable, which can control the endogeneity caused by the lack of a dependent variable, resulting in greater accuracy. The differential GMM estimator (DIF-GMM) and system GMM estimator (SYSGMM) methods are generally used to estimate the dynamic panel model [25]. The SYS-GMM combines DIF-GMM with level GMM. It uses the lag term of the horizontal value as the tool variable of the difference equation, selects the lag term of the difference variable as the tool variable of the horizontal equation, and estimates the difference equation and horizontal equation as an equation system [26]. The SYS-GMM improves the effectiveness, consistency, and efficiency of estimation [27]. According to the weight matrix, the SYSGMM method can be divided into a one-step method and a two-step method. The two-step method is not easily disturbed by heteroscedasticity. Therefore, this paper mainly uses the two-step SYS-GMM method to analyze the dynamic panel econometric model. In addition, pooled ordinary least squares (OLS) and fixed effect models are used to assist the analysis, which is tested from the perspective of various empirical analyses.

2.3. Data Description. The YRD is the largest urban economic region in China and is an important engine of China's economic growth. In June 2019, the YRD MI development plan was compiled and implemented, and 27 cities were identified as central cities. These are Shanghai, Nanjing, Wuxi, Changzhou, Suzhou, Nantong, Yangzhou, Zhenjiang, Yancheng, and Taizhou in Jiangsu Province; Hangzhou, Ningbo, Shaoxing, Jiaxing, Huzhou, Wenzhou, Taizhou, Jinhua, and Zhoushan in Zhejiang Province; and Hefei, Chuzhou, Ma'anshan, Wuhu, Xuancheng, Tongling, Chizhou, and Anqing in Anhui Province. The original data are from the 2010-2019 "China Urban Statistical Yearbook," "China Urban Construction Yearbook," and the corresponding statistical yearbooks of the 27 cities. Missing values are filled by interpolation.

\subsection{Variables' Selection}

2.4.1. RI. Patents are often used to describe levels of RI [23]. This paper uses the per capita patent application acceptance of each city to characterize RI.

2.4.2. Measurement of the MI Index. The main measurement methodologies of the MI index include the production method, price method, trade law method, business cycle method, and questionnaire survey method. The price method is the most widely used of these methods. Referring to Parsley and Wei [28] and Zhang et al. [17], this paper uses the "price index method" to calculate the relative price variance and selects three-dimensional $(t \times i \times k)$ panel data where $t$ is the year, $i$ is the city, and $k$ is the commodity. This paper uses 16 kinds of commodities: food; drinks, tobacco, and wine; clothing, shoes, and hats; textiles; household appliances and audio-visual equipment; cultural and office supplies; daily necessities; sports and entertainment supplies; transportation and communication supplies; furniture; cosmetics; gold and silver jewelry; Chinese and Western medicine and medical and healthcare products; books, newspapers, magazines, and electronic publications; fuel; building materials and hardware. The retail price index of commodities selected in this paper uses the chained data of the previous period as the base period, so the relative price form set is the first-order difference form of relative price. The formula is as follows:

$$
\Delta Q_{i, j}^{k}=\ln \left(\frac{p_{i, t}^{k}}{p_{j, t}^{k}}\right)-\ln \left(\frac{p_{i, t-1}^{k}}{p_{j, t-1}^{k}}\right)=\ln \left(\frac{p_{i, t}^{k}}{p_{i, t-1}^{k}}\right)-\ln \left(\frac{p_{j, t}^{k}}{p_{j, t-1}^{k}}\right),
$$

where $\Delta Q_{i, j}^{k}$ is the first-order difference of relative prices, $p_{i, t}^{k}$ and $p_{i, t-1}^{k}$ represent the retail price index of $k$-type commodities in periods $t$ and $t-1$ in city $i$, and $p_{j, t}^{k}$ and $p_{j, t-1}^{k}$ represent the retail price index of class $k$ commodities in periods $t$ and $t-1$ in city $j$, respectively. In this paper, the absolute value form $\left|\Delta Q_{i, j}^{k}\right|$ of the first-order difference of relative price is selected to eliminate the influence of the difference form symbol on relative price variance. Through the above calculation, we can obtain the absolute values $\left|\Delta Q_{i, j}^{k}\right|$ of 59,160 first-order relative prices of 351 pairs of 16 types of commodities from 2009 to 2018.

To eliminate the price changes unrelated to regional market environment differences, referring to Bian et al. [15], 
the deaveraging method is used to address relative prices. Suppose $\left|\Delta Q_{i, j}^{k}\right|=\alpha^{k}+\varepsilon_{i, j, t}^{k}$, where $\alpha^{k}$ is the price change caused by the nature of class $k$ commodity, and $\varepsilon_{i, j, t}^{k}$ is the price change caused by the different market environments between regions $i$ and $j$.

To eliminate the fixed effect $\alpha^{k}$, the relative price $\overline{\left|\Delta Q_{i, j}^{k}\right|}$ of 351 pairs of city combinations is averaged under the conditions of given time $t$ and commodity type $k$. The difference $q_{i, j, t}^{k}$ between the two is the basis for calculating the relative price variance in this paper. The above calculation process can be expressed as follows:

$$
\left|\Delta Q_{i, j}^{k}\right|-\overline{\Delta Q_{i, j}^{k} \mid}=\left(\alpha^{k}-\overline{\alpha^{k}}\right)+\left(\varepsilon_{i, j, t}^{k}-\overline{\varepsilon_{i, j, t}^{k}}\right)=\varepsilon_{i, j, t}^{k}-\overline{\varepsilon_{i, j, t}^{k}}=q_{i, j, t}^{k} .
$$

Combining the relative price variance of 351 pairs of cities corresponding to 27 cities and taking the reciprocal after the square root, we can obtain the MI index of each city.

2.4.3. Other Control Variables. In addition to MI, other control variables, such as government support, tertiary industry, information technology, foreign trade dependence, economic development, and transportation infrastructure, may also affect RI. (1) Government support (GOV): the level of government support for scientific and technological innovation is primarily reflected by funding. Therefore, the proportion of government financial expenditure on science and technology in GDP is used as the government support index. (2) Tertiary industry (PTI) is characterized by the proportion of added value of tertiary industry in GDP. (3) Informatization (INT) is characterized by the number of broadband users in each city. (4) Foreign investment dependence (FDI) is characterized by the proportion of foreign capital spent in each city in GDP. The actual amount of foreign capital utilized is converted by the average exchange rate of RMB to US dollars in the current year. (5) Economic development (GDP) is expressed as the per capita GDP of each city. The GDP per capita index uses 1999 as the base year to convert the data into per capita constant price GDP. (6) Transport infrastructure (TR) is represented by the per capita road area of each city. Table 1 reports the descriptive statistical results of the above variables.

\section{Results and Discussion}

3.1. Multicollinearity Test. A Pearson correlation test was performed on the correlation between variables and the results are shown in Table 2. Except for the correlation coefficient of economic development, RI, and tertiary industry being higher than 0.7 , the correlation coefficients of the other variables are all lower than 0.7.

To further investigate the multicollinearity between variables, the results of the diagnostic test using the variance expansion factor (VIF) are shown in Table 3. The VIF of each explanatory variable is lower than 3.59. If the VIF is greater than 5, then there is multicollinearity [29]. Therefore, there is no multicollinearity between explanatory variables, and the next empirical analysis can be carried out.
3.2. Panel Unit Root Tests. To prevent false regression, the unit root test is used to test the stability of the variables. This paper adopts five methods: ADF-Fisher, PP-Fisher, LLC, HT, and IPS W-stat. Due to space constraints, only the firstorder difference results are reported in Table 4. The five methods all show that the horizontal values of each variable are nonstationary and have the same-order single integer; that is, there is a unit root, but the first-order difference of each variable is stable. Thus, they belong to the first-order single-integral I(1) sequence and can be estimated by regression.

3.3. Basic Statistical Observation. According to the method described above, this paper measures the MI index of cities in the YRD from 2009 to 2018. The larger the index, the higher the level of regional integration. Its average is shown in Figure 1. Despite relapses in certain years, the overall MI index of the YRD rises from 26.364 in 2009 to 40.214 in 2018.

According to the natural break point classification method, the spatial distribution of the MI index in the YRD from 2009 to 2018 is drawn. As shown in Figure 2, the MI index is divided into five levels, from low to high. The MI index is $31.447-32.577$ at the first level, 33.058-34.469 at the second level, 34.887-36.090 at the third level, 36.318-37.464 at the fourth level, and 38.592-39.412 at the fifth level. The cities in the first tier are Changzhou, Chizhou, and Taizhou. Nanjing, Jinhua, Wuxi, Suzhou, Shanghai, Shaoxing, Hangzhou, and Yancheng comprise the second tier. Wuhu, Tongling, Ningbo, Ma'anshan, Nantong, Taizhou, and Jiaxing make up the third tier. Anqing, Wenzhou, Zhenjiang, Chuzhou, Yangzhou, Huzhou, and Zhoushan are in the fourth tier. Finally, Xuancheng and Hefei have the highest MI index values.

Using the above methods, the spatial distribution of innovation in the YRD from 2009 to 2018 is drawn. As shown in Figure 3, RI is divided into five levels from low to high. The cities in the first tier are Anqing, Xuancheng, Chizhou, Chuzhou, Zhoushan, and Yancheng. Ma'anshan, Tongling, Jinhua, Taizhou, and Wenzhou are in the second tier. Hefei, Yangzhou, Taizhou, Nantong, Wuhu, and Shanghai are in the third tier. Jiaxing, Huzhou, Zhenjiang, Shaoxing, Nanjing, Hangzhou, Changzhou, and Ningbo are in the fourth tier. Finally, Wuxi and Suzhou are in the fifth tier.

\subsection{Model Estimation Results and Analysis}

3.4.1. Static Model Estimation Results. Based on the panel data of 27 cities in the YRD from 2009 to 2018, the static panel estimation method is used to estimate equation (1). To verify the robustness of the parameter estimation results, we introduced variables one by one to conduct regression analysis on the model. The results are shown in Models 1-7 in Table 5. The pooled OLS and the panel fixation effect both show that the coefficient of urban integration is significantly positive, indicating that $\mathrm{MI}$ is conducive to RI.

$\mathrm{MI}$ and RI are both long-term processes, and the impact of $\mathrm{MI}$ on RI can be better explained from a dynamic 
TABLE 1: The descriptive statistics of variables.

\begin{tabular}{|c|c|c|c|c|c|c|}
\hline Variable & Unit & Mean & Maximum & Minimum & Std. deviation & Observations \\
\hline RI & Piece/person & 0.005 & 0.022 & 0.000 & 0.004 & 270 \\
\hline MI & - & 35.264 & 57.053 & 11.864 & 8.360 & 270 \\
\hline GOV & $\%$ & 3.876 & 13.088 & 0.690 & 1.905 & 270 \\
\hline PTI & $\%$ & 43.880 & 69.900 & 23.360 & 9.055 & 270 \\
\hline INT & 10000 households & 155.160 & 875.000 & 6.949 & 146.550 & 270 \\
\hline FDI & $\%$ & 3.149 & 8.988 & 0.193 & 1.850 & 270 \\
\hline GDP & RMB/person & 51683.380 & 144172.300 & 13811.000 & 21421.590 & 270 \\
\hline $\mathrm{TR}$ & $\mathrm{km}^{2} /$ person & 19.756 & 41.220 & 4.040 & 6.099 & 270 \\
\hline
\end{tabular}

TABLE 2: Pearson correlation test.

\begin{tabular}{|c|c|c|c|c|c|c|c|}
\hline Variable & $\ln M I$ & $\ln \mathrm{GOV}$ & $\ln \mathrm{PTI}$ & $\operatorname{lnINT}$ & $\operatorname{lnFDI}$ & $\operatorname{lnGDP}$ & $\ln \mathrm{TR}$ \\
\hline $\ln M I$ & 1 & & & & & & \\
\hline $\ln \mathrm{GOV}$ & $\begin{array}{l}0.123^{* *} \\
(0.044)\end{array}$ & 1 & & & & & \\
\hline $\ln \mathrm{PTI}$ & $\begin{array}{c}0.187^{* * *} \\
(0.002)\end{array}$ & $\begin{array}{c}0.292^{* * *} \\
(0.000)\end{array}$ & 1 & & & & \\
\hline $\operatorname{lnINT}$ & $\begin{array}{c}0.223^{* * *} \\
(0.000)\end{array}$ & $\begin{array}{c}0.495^{* * *} \\
(0.000)\end{array}$ & $\begin{array}{c}0.790^{* * *} \\
(0.000)\end{array}$ & 1 & & & \\
\hline $\operatorname{lnFDI}$ & $\begin{array}{c}-0.179^{* * *} \\
(0.003)\end{array}$ & $\begin{array}{c}0.250^{* * *} \\
(0.000)\end{array}$ & $\begin{array}{c}0.258^{* * *} \\
(0.000)\end{array}$ & $\begin{array}{c}-0.188^{* * *} \\
(0.002)\end{array}$ & 1 & & \\
\hline $\operatorname{lnGDP}$ & $\begin{array}{c}0.007 \\
(0.911)\end{array}$ & $\begin{array}{c}0.613^{* * *} \\
(0.000)\end{array}$ & $\begin{array}{c}0.481^{* * *} \\
(0.000)\end{array}$ & $\begin{array}{c}0.545^{* * *} \\
(0.000)\end{array}$ & $\begin{array}{c}0.159^{* * *} \\
(0.009)\end{array}$ & 1 & \\
\hline $\ln T R$ & $\begin{array}{c}0.050 \\
(0.418)\end{array}$ & $\begin{array}{c}-0.155^{* *} \\
(0.011)\end{array}$ & $\begin{array}{l}-0.085 \\
(0.165) \\
\end{array}$ & $\begin{array}{c}-0.139^{* *} \\
(0.022)\end{array}$ & $\begin{array}{l}-0.099 \\
(0.106)\end{array}$ & $\begin{array}{l}-0.083 \\
(0.174)\end{array}$ & 1 \\
\hline
\end{tabular}

Note. $^{* * *}$ and ${ }^{* *}$, respectively, indicate significance at the level of $1 \%$ and $5 \%$. The number in ( ) is the $P$ value.

TABLE 3: Variance expansion factor test (VIF).

\begin{tabular}{lcr}
\hline Variable & VIF & $1 /$ VIF \\
\hline $\ln$ MI & 1.627 & 0.615 \\
$\ln$ GOV & 1.396 & 0.716 \\
$\ln$ TI & 3.087 & 0.324 \\
$\ln I$ NT & 3.581 & 0.279 \\
$\ln$ FDI & 1.230 & 0.813 \\
$\ln$ GDP & 1.156 & 0.865 \\
$\ln$ TR & 1.635 & 0.612 \\
\hline
\end{tabular}

TABLE 4: Results of panel unit root tests.

\begin{tabular}{|c|c|c|c|c|c|}
\hline & ADF-Fisher & PP-Fisher & LLC & HT & IPS W-stat \\
\hline $\ln R I$ & $103.078^{* * *}$ & $189.137^{* * *}$ & $-7.290^{* * *}$ & $3.529^{* * *}$ & $-3.323^{* * *}$ \\
\hline $\ln M I$ & $100.920^{* * *}$ & $222.740^{* * *}$ & $-6.850^{* * *}$ & $4.995^{* * *}$ & $-3.238^{* * *}$ \\
\hline $\ln \mathrm{GOV}$ & $126.899^{* * *}$ & $263.897^{* * *}$ & $-10.560^{* * *}$ & $4.721^{* * *}$ & $-4.781^{* * *}$ \\
\hline $\operatorname{lnPTI}$ & $119.935^{* * *}$ & $206.487^{* * *}$ & $-12.839^{* * *}$ & $7.103^{* * *}$ & $-2.487^{* * *}$ \\
\hline $\operatorname{lnINT}$ & $169.752^{* * *}$ & $195.645^{* * *}$ & $-48.613^{* * *}$ & $7.182^{* * *}$ & $-12.722^{* * *}$ \\
\hline $\operatorname{lnFDI}$ & $131.228^{* * *}$ & $173.065^{* * *}$ & $-11.287^{* * *}$ & $4.576^{* * *}$ & $-5.371^{* * *}$ \\
\hline $\operatorname{lnGDP}$ & $176.593^{* * *}$ & $276.948^{* * *}$ & $-15.695^{* * *}$ & $3.744^{* * *}$ & $-8.063^{* * *}$ \\
\hline $\operatorname{lnTR}$ & $146.521^{* * *}$ & $187.248^{* * *}$ & $-14.261^{* * *}$ & $4.340^{* * *}$ & $-6.226^{* * *}$ \\
\hline
\end{tabular}

Note. $^{* * *}$ indicates significance at the level of $1 \%$.

perspective. Therefore, using static panel model regression, the first-order lag of RI is added to establish a dynamic panel model to estimate equation (2). The GMM is adopted in this paper because it can effectively deal with endogeneity problems [30,31]. To make the estimation results robust, this paper uses the DIF-GMM model and the SYS-GMM model to investigate the impact of MI on RI. The results are shown in Table 6. GMM requires that there be no either secondorder or higher-order autocorrelation in the residual series of samples and that the instrumental variables are strictly 


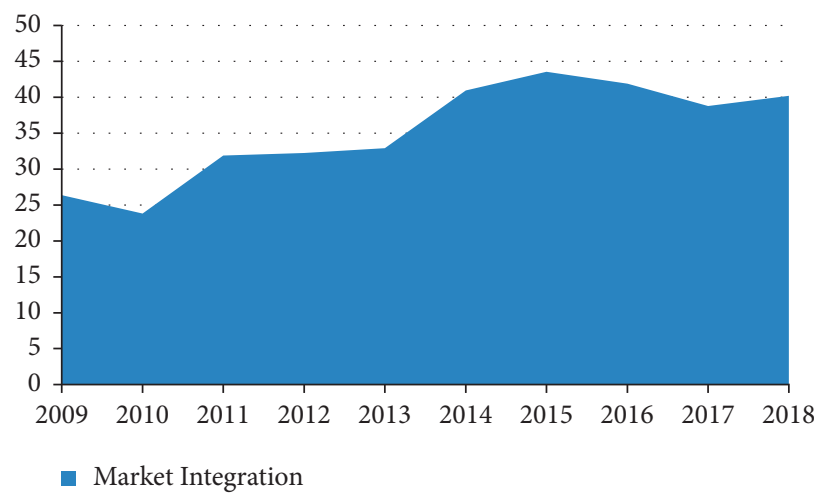

FIgURE 1: MI in YRD of China during the period of 2009-2018.

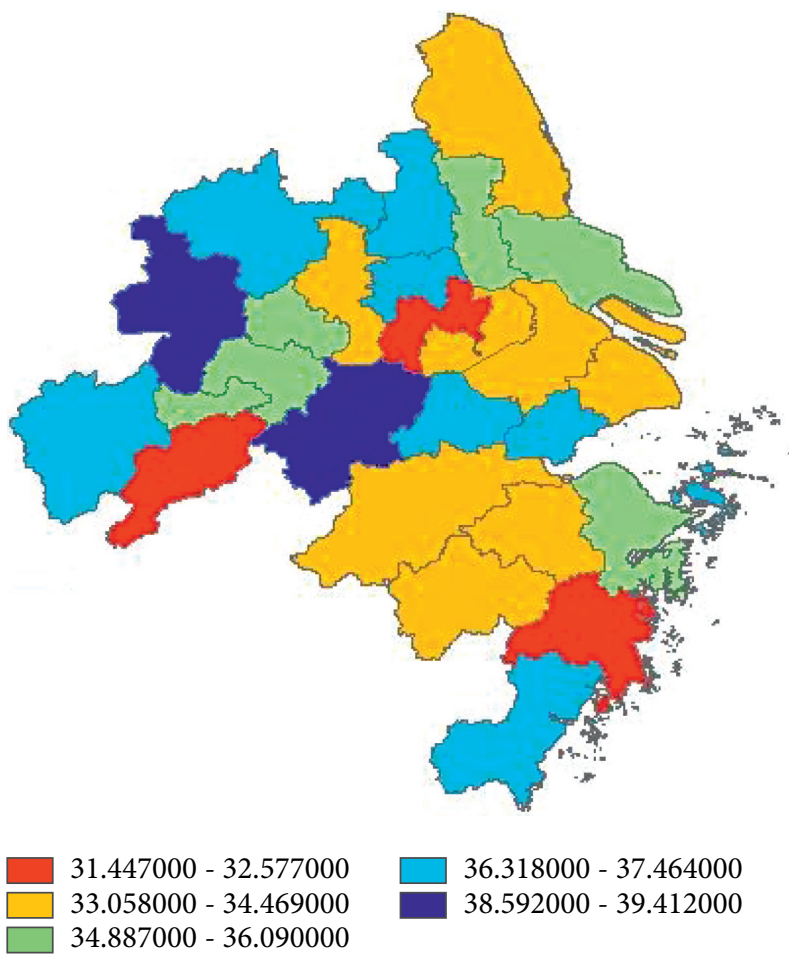

FIGURE 2: MI Spatial distribution in YRD of China during the period of 2009-2018.

exogenous. Therefore, the Arellano-Bond (AR) sequence correlation test and the Sargan test are needed for the estimation results [32].

In Models 1-7 of DIF-GMM, the $P$ values of AR (1) were $0.038,0.023,0.031,0.045,0.038,0.039$, and 0.040 , respectively. The $P$ values of AR (2) were $0.859,0.878,0.844,0.745$, $0.929,0.928$, and 0.963 , respectively. The results show that there is a first-order negative correlation in the residual sequence of the sample, but that there is no second-order or higher sequence correlation. The dynamic model has passed the correlation test. In addition, the Sargan test is needed to identify whether the tool variables are valid. In DIF-GMM, the $P$ values of the Sargan test were 0.813, 0.997, 0.999, 0.997, $0.998,0.998$, and 0.374 , respectively. Therefore, the original hypothesis is accepted, and the instrumental variables are valid. In Models 1-7 of DIF-GMM, the $P$ values of AR (1) were $0.036,0.026,0.031,0.043,0.038,0.044$, and 0.036 , respectively. The $P$ values of AR (2) were $0.949,0.958,0.890$, $0.766,0.920,0.921$, and 0.851 , respectively. There is a firstorder negative correlation in the residual sequence of the sample, but there is no second-order or above sequence correlation. The $P$ values of the Sargan test were 0.997, 1.000, $1.000,1.000,1.000,1.000$, and 1.000, respectively. Therefore, if we accept the original hypothesis, the instrumental variable is valid. The Arellano-Bond and Sargan tests show that the selection of tool variables of the DIF-GMM and SYSGMM models in Table 6 is reasonable, the model identification is effective, and the estimation results are reliable. 


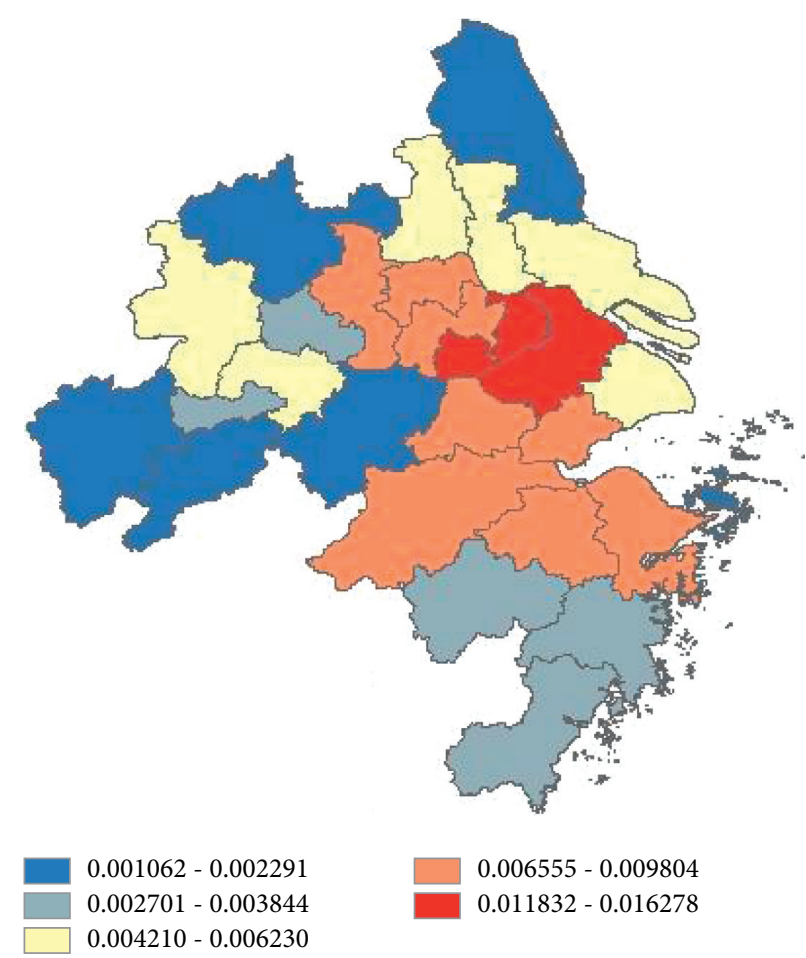

FIGURE 3: RI in YRD of China during the period of 2009-2018.

Table 5: Static test of the impact of MI on RI.

\begin{tabular}{|c|c|c|c|c|c|c|c|}
\hline & \multicolumn{7}{|c|}{ Pool OLS } \\
\hline & Model 1 & Model 2 & Model 3 & Model 4 & Model 5 & Model 6 & Model 7 \\
\hline $\ln M I$ & $\begin{array}{c}1.061^{* * *} \\
(0.227)\end{array}$ & $\begin{array}{c}0.777^{* * * *} \\
(0.180)\end{array}$ & $\begin{array}{c}0.559^{* * * *} \\
(0.163)\end{array}$ & $\begin{array}{c}0.465^{* * *} \\
(0.154)\end{array}$ & $\begin{array}{c}0.554^{* * *} \\
(0.153)\end{array}$ & $\begin{array}{c}0.732^{* * *} \\
(0.137)\end{array}$ & $\begin{array}{c}0.653^{* * *} \\
(0.123)\end{array}$ \\
\hline $\ln \mathrm{GOV}$ & & $\begin{array}{c}1.269^{* * *} \\
(0.099)\end{array}$ & $\begin{array}{c}1.057^{* * *} \\
(0.091)\end{array}$ & $\begin{array}{c}0.804^{* * *} \\
(0.096)\end{array}$ & $\begin{array}{c}0.663^{* * *} \\
(0.102)\end{array}$ & $\begin{array}{c}0.280^{* * *} \\
(0.100)\end{array}$ & $\begin{array}{c}0.339^{* * *} \\
(0.091)\end{array}$ \\
\hline $\ln \mathrm{PTI}$ & & & $\begin{array}{c}1.740^{* * *} \\
(0.207) \\
\end{array}$ & $\begin{array}{c}0.360 \\
(0.306) \\
\end{array}$ & $\begin{array}{c}0.486 \\
(0.302) \\
\end{array}$ & $\begin{array}{r}-0.086 \\
(0.275) \\
\end{array}$ & $\begin{array}{l}-0.076 \\
(0.247) \\
\end{array}$ \\
\hline $\operatorname{lnINT}$ & & & & $\begin{array}{c}0.428^{* * *} \\
(0.073)\end{array}$ & $\begin{array}{c}0.465^{* * *} \\
(0.072)\end{array}$ & $\begin{array}{c}0.400^{* * *} \\
(0.064)\end{array}$ & $\begin{array}{c}0.442^{* * *} \\
(0.058)\end{array}$ \\
\hline $\operatorname{lnFDI}$ & & & & & $\begin{array}{c}0.202^{* * *} \\
(0.056)\end{array}$ & $\begin{array}{c}0.128^{* *} \\
(0.050)\end{array}$ & $\begin{array}{c}0.162^{* * *} \\
(0.046)\end{array}$ \\
\hline $\operatorname{lnGDP}$ & & & & & & $\begin{array}{c}0.924^{* * *} \\
(0.106)\end{array}$ & $\begin{array}{c}0.971^{* * *} \\
(0.095)\end{array}$ \\
\hline $\ln T R$ & & & & & & & $\begin{array}{c}0.613^{* * *} \\
(0.077)\end{array}$ \\
\hline Cons & $\begin{array}{c}-9.349^{* * *} \\
(0.806) \\
\end{array}$ & $\begin{array}{c}-9.926^{* * *} \\
(0.637) \\
\end{array}$ & $\begin{array}{c}-15.435^{* * *} \\
(0.868)\end{array}$ & $\begin{array}{c}-11.583^{* * *} \\
(1.051)\end{array}$ & $\begin{array}{c}-12.548^{* * *} \\
(1.064) \\
\end{array}$ & $\begin{array}{c}-20.124^{* * *} \\
(1.281)\end{array}$ & $\begin{array}{c}-21.415^{* * *} \\
(1.165) \\
\end{array}$ \\
\hline$R^{2}$ & 0.075 & 0.427 & 0.546 & 0.598 & 0.616 & 0.702 & 0.759 \\
\hline & & & & $\mathrm{FE}$ & & & \\
\hline $\ln M I$ & $\begin{array}{c}1.421^{* * *} \\
(0.142)\end{array}$ & $\begin{array}{c}1.107^{* * *} \\
(0.137)\end{array}$ & $\begin{array}{c}0.774^{* * *} \\
(0.137)\end{array}$ & $\begin{array}{c}0.419^{* * *} \\
(0.141)\end{array}$ & $\begin{array}{c}0.492^{* * *} \\
(0.147)\end{array}$ & $\begin{array}{c}0.432^{* * *} \\
(0.140)\end{array}$ & $\begin{array}{c}0.422^{* * *} \\
(0.142)\end{array}$ \\
\hline $\ln \mathrm{GOV}$ & & $\begin{array}{c}1.140^{* * *} \\
(0.161)\end{array}$ & $\begin{array}{c}0.831^{* * *} \\
(0.157)\end{array}$ & $\begin{array}{c}0.423^{* * *} \\
(0.161)\end{array}$ & $\begin{array}{c}0.398^{* *} \\
(0.162)\end{array}$ & $\begin{array}{l}0.289^{*} \\
(0.155)\end{array}$ & $\begin{array}{l}0.301^{*} \\
(0.156)\end{array}$ \\
\hline
\end{tabular}


TABLE 5: Continued.

\begin{tabular}{|c|c|c|c|c|c|c|c|}
\hline & & & & Pool OLS & & & \\
\hline & Model 1 & Model 2 & Model 3 & Model 4 & Model 5 & Model 6 & Model 7 \\
\hline $\ln \mathrm{PTI}$ & & & $\begin{array}{c}1.874^{* * *} \\
(0.297)\end{array}$ & $\begin{array}{c}0.550 \\
(0.354)\end{array}$ & $\begin{array}{l}0.676^{*} \\
(0.361)\end{array}$ & $\begin{array}{c}0.984^{* * *} \\
(0.348)\end{array}$ & $\begin{array}{c}1.051^{* * *} \\
(0.370)\end{array}$ \\
\hline $\operatorname{lnINT}$ & & & & $\begin{array}{c}0.671^{* * *} \\
(0.111)\end{array}$ & $\begin{array}{c}0.664^{* * *} \\
(0.111)\end{array}$ & $\begin{array}{c}0.530^{* * *} \\
(0.108)\end{array}$ & $\begin{array}{c}0.536^{* * *} \\
(0.109)\end{array}$ \\
\hline $\operatorname{lnFDI}$ & & & & & $\begin{array}{c}0.147 \\
(0.090)\end{array}$ & $\begin{array}{l}0.172^{* *} \\
(0.085)\end{array}$ & $\begin{array}{l}0.174^{* *} \\
(0.085)\end{array}$ \\
\hline $\ln G D P$ & & & & & & $\begin{array}{c}1.289^{* * *} \\
(0.248)\end{array}$ & $\begin{array}{c}1.316^{* * *} \\
(0.253)\end{array}$ \\
\hline $\ln T R$ & & & & & & & $\begin{array}{l}-0.137 \\
(0.254) \\
\end{array}$ \\
\hline Cons & $\begin{array}{c}-10.620^{* * * *} \\
(0.503)\end{array}$ & $\begin{array}{c}-10.932^{* * *} \\
(0.461)\end{array}$ & $\begin{array}{c}-16.418^{* * *} \\
(0.971)\end{array}$ & $\begin{array}{c}-12.779^{* * *} \\
(1.089)\end{array}$ & $\begin{array}{c}-12.902^{* * *} \\
(1.088)\end{array}$ & $\begin{array}{c}-26.977^{* * *} \\
(2.833)\end{array}$ & $\begin{array}{c}-27.021^{* * *} \\
(2.900)\end{array}$ \\
\hline$R^{2}$ & 0.075 & 0.417 & 0.535 & 0.561 & 0.586 & 0.677 & 0.658 \\
\hline
\end{tabular}

Notes: standard errors of coefficients are reported in parentheses; ${ }^{*},{ }^{* *}$, and ${ }^{* * *}$ indicate that the coefficients are statistically significant at $10 \%, 5 \%$, and $1 \%$ levels, respectively.

TABle 6: Dynamic test of the impact of MI on RI.

\begin{tabular}{|c|c|c|c|c|c|c|c|}
\hline \multirow[b]{2}{*}{ Variable } & \multicolumn{5}{|c|}{ DIF-GMM } & \multirow[b]{2}{*}{ Model 6} & \multirow[b]{2}{*}{ Model 7} \\
\hline & Model 1 & Model 2 & Model 3 & Model 4 & Model 5 & & \\
\hline$L_{1} \cdot \ln R I$ & $\begin{array}{c}0.597^{* * *} \\
(0.013)\end{array}$ & $\begin{array}{c}0.511^{* * *} \\
(0.011)\end{array}$ & $\begin{array}{c}0.446^{* * *} \\
(0.014)\end{array}$ & $\begin{array}{c}0.377^{* * *} \\
(0.023)\end{array}$ & $\begin{array}{c}0.398^{* * *} \\
(0.021)\end{array}$ & $\begin{array}{c}0.349^{* * *} \\
(0.022)\end{array}$ & $\begin{array}{c}0.409^{* * *} \\
(0.045)\end{array}$ \\
\hline $\ln M I$ & $\begin{array}{c}0.549^{* * *} \\
(0.050)\end{array}$ & $\begin{array}{c}0.379^{* * *} \\
(0.036)\end{array}$ & $\begin{array}{c}0.340^{* * *} \\
(0.029)\end{array}$ & $\begin{array}{c}0.310^{* * *} \\
(0.032)\end{array}$ & $\begin{array}{c}0.399^{* * *} \\
(0.027)\end{array}$ & $\begin{array}{c}0.350^{* * *} \\
(0.047)\end{array}$ & $\begin{array}{c}0.443^{* * *} \\
(0.056)\end{array}$ \\
\hline $\operatorname{lnGOV}$ & & $\begin{array}{c}0.969^{* * *} \\
(0.084)\end{array}$ & $\begin{array}{c}0.733^{* * *} \\
(0.129)\end{array}$ & $\begin{array}{c}0.257^{* * *} \\
(0.033)\end{array}$ & $\begin{array}{c}0.411^{* * *} \\
(0.109)\end{array}$ & $\begin{array}{c}0.381^{* * *} \\
(0.040)\end{array}$ & $\begin{array}{c}0.160^{* * *} \\
(0.053)\end{array}$ \\
\hline $\operatorname{lnPTI}$ & & & $\begin{array}{c}0.771^{* * *} \\
(0.119)\end{array}$ & $\begin{array}{c}0.522^{* * *} \\
(0.174)\end{array}$ & $\begin{array}{c}0.386^{* * *} \\
(0.138)\end{array}$ & $\begin{array}{c}0.788^{* * *} \\
(0.234)\end{array}$ & $\begin{array}{c}0.539^{* * *} \\
(0.159)\end{array}$ \\
\hline $\operatorname{lnINT}$ & & & & $\begin{array}{c}0.300^{* * *} \\
(0.050)\end{array}$ & $\begin{array}{c}0.307^{* * *} \\
(0.035)\end{array}$ & $\begin{array}{c}0.204^{* * *} \\
(0.057)\end{array}$ & $\begin{array}{c}0.166^{* * *} \\
(0.030)\end{array}$ \\
\hline $\operatorname{lnFDI}$ & & & & & $\begin{array}{c}0.290^{* * *} \\
(0.027)\end{array}$ & $\begin{array}{c}0.265^{* * *} \\
(0.028)\end{array}$ & $\begin{array}{c}0.301^{* * *} \\
(0.025)\end{array}$ \\
\hline $\operatorname{lnGDP}$ & & & & & & $\begin{array}{c}1.052^{* * *} \\
(0.122)\end{array}$ & $\begin{array}{c}0.863^{* * *} \\
(0.194) \\
\end{array}$ \\
\hline $\ln T R$ & & & & & & $\begin{array}{c}0.265^{* * *} \\
(0.028)\end{array}$ & $\begin{array}{l}0.170^{*} \\
(0.095)\end{array}$ \\
\hline Cons & $\begin{array}{c}-4.052^{* * *} \\
(0.233) \\
\end{array}$ & $\begin{array}{c}-5.156^{* * *} \\
(0.176) \\
\end{array}$ & $\begin{array}{c}-7.994^{* * *} \\
(0.518) \\
\end{array}$ & $\begin{array}{c}-8.160^{* * *} \\
(0.585) \\
\end{array}$ & $\begin{array}{c}-6.980^{* * *} \\
(0.554) \\
\end{array}$ & $\begin{array}{c}19.520^{* * *} \\
(1.462) \\
\end{array}$ & $\begin{array}{c}-16.457^{* * *} \\
(2.631)\end{array}$ \\
\hline Wald test & $\begin{array}{c}3784.95 \\
(0.000) \\
\end{array}$ & $\begin{array}{c}4926.90 \\
(0.000) \\
\end{array}$ & $\begin{array}{c}5932.03 \\
(0.000) \\
\end{array}$ & $\begin{array}{c}9268.69 \\
(0.000) \\
\end{array}$ & $\begin{array}{c}6645.31 \\
(0.000) \\
\end{array}$ & $\begin{array}{c}3580.23 \\
(0.000) \\
\end{array}$ & $\begin{array}{l}3699.41 \\
(0.000)\end{array}$ \\
\hline $\begin{array}{l}\operatorname{AR}(1) \\
\operatorname{AR}(2)\end{array}$ & $\begin{array}{l}0.038 \\
0.859\end{array}$ & $\begin{array}{l}0.023 \\
0.878\end{array}$ & $\begin{array}{l}0.031 \\
0.844\end{array}$ & $\begin{array}{l}0.045 \\
0.745\end{array}$ & $\begin{array}{l}0.038 \\
0.929\end{array}$ & $\begin{array}{l}0.039 \\
0.928\end{array}$ & $\begin{array}{l}0.040 \\
0.963\end{array}$ \\
\hline Sargan test & $\begin{array}{l}26.588 \\
(0.813)\end{array}$ & $\begin{array}{l}24.925 \\
(0.997)\end{array}$ & $\begin{array}{l}24.053 \\
(0.999)\end{array}$ & $\begin{array}{c}25.133 \\
(0.997)\end{array}$ & $\begin{array}{c}24.134 \\
(0.998)\end{array}$ & $\begin{array}{l}24.430 \\
(0.998)\end{array}$ & $\begin{array}{l}22.449 \\
(0.374)\end{array}$ \\
\hline \multicolumn{8}{|c|}{ SYS-GMM } \\
\hline$L_{1} \cdot \ln R I$ & $\begin{array}{c}0.666^{* * *} \\
(0.008)\end{array}$ & $\begin{array}{c}0.600^{* * *} \\
(0.017)\end{array}$ & $\begin{array}{c}0.461^{* * *} \\
(0.016)\end{array}$ & $\begin{array}{c}0.377^{* * *} \\
(0.022)\end{array}$ & $\begin{array}{c}0.431^{* * *} \\
(0.014)\end{array}$ & $\begin{array}{c}0.367^{* * *} \\
(0.020)\end{array}$ & $\begin{array}{c}0.384^{* * *} \\
(0.030)\end{array}$ \\
\hline $\operatorname{lnMI}$ & $\begin{array}{c}0.386^{* * *} \\
(0.032) \\
\end{array}$ & $\begin{array}{c}0.205^{* * *} \\
(0.030) \\
\end{array}$ & $\begin{array}{c}0.200^{* * *} \\
(0.044) \\
\end{array}$ & $\begin{array}{c}0.276^{* * *} \\
(0.035) \\
\end{array}$ & $\begin{array}{c}0.306^{* * *} \\
(0.040) \\
\end{array}$ & $\begin{array}{c}0.377^{* * *} \\
(0.049) \\
\end{array}$ & $\begin{array}{c}0.429^{* * *} \\
(0.069) \\
\end{array}$ \\
\hline $\operatorname{lnGOV}$ & & $\begin{array}{c}0.834^{* * *} \\
(0.097)\end{array}$ & $\begin{array}{c}0.721^{* * *} \\
(0.117)\end{array}$ & $\begin{array}{c}0.329^{* * *} \\
(0.034)\end{array}$ & $\begin{array}{c}0.390^{* * *} \\
(0.113)\end{array}$ & $\begin{array}{c}0.228^{* * *} \\
(0.034)\end{array}$ & $\begin{array}{c}0.492^{* *} \\
(0.200)\end{array}$ \\
\hline
\end{tabular}


TABLE 6: Continued.

\begin{tabular}{|c|c|c|c|c|c|c|c|}
\hline \multirow[b]{2}{*}{ Variable } & \multicolumn{5}{|c|}{ DIF-GMM } & \multirow[b]{2}{*}{ Model 6} & \multirow[b]{2}{*}{ Model 7} \\
\hline & Model 1 & Model 2 & Model 3 & Model 4 & Model 5 & & \\
\hline $\ln \mathrm{PTI}$ & & & $\begin{array}{c}1.051^{* * *} \\
(0.107)\end{array}$ & $\begin{array}{c}0.568^{* * *} \\
(0.140)\end{array}$ & $\begin{array}{c}0.594^{* * *} \\
(0.165)\end{array}$ & $\begin{array}{c}0.945^{* * *} \\
(0.232)\end{array}$ & $\begin{array}{l}0.472^{*} \\
(0.255)\end{array}$ \\
\hline $\operatorname{lnINT}$ & & & & $\begin{array}{c}0.272^{* * *} \\
(0.035)\end{array}$ & $\begin{array}{c}0.279^{* * *} \\
(0.034)\end{array}$ & $\begin{array}{c}0.181^{* * *} \\
(0.057)\end{array}$ & $\begin{array}{c}0.206^{* * *} \\
(0.057)\end{array}$ \\
\hline $\operatorname{lnFDI}$ & & & & & $\begin{array}{c}0.174^{* * *} \\
(0.024) \\
\end{array}$ & $\begin{array}{c}0.213^{* * *} \\
(0.028) \\
\end{array}$ & $\begin{array}{c}0.179^{* * *} \\
(0.029)\end{array}$ \\
\hline $\operatorname{lnGDP}$ & & & & & & $\begin{array}{c}0.505^{* * *} \\
(0.130)\end{array}$ & $\begin{array}{c}0.453^{* * *} \\
(0.142)\end{array}$ \\
\hline $\ln T R$ & & & & & & & $\begin{array}{c}0.167^{*} \\
(0.093)\end{array}$ \\
\hline Cons & $\begin{array}{c}-3.081^{* * *} \\
(0.149) \\
\end{array}$ & $\begin{array}{c}-3.857^{* * *} \\
(0.245) \\
\end{array}$ & $\begin{array}{c}-8.467^{* * *} \\
(0.379)\end{array}$ & $\begin{array}{c}-8.169^{* * *} \\
(0.510)\end{array}$ & $\begin{array}{c}-7.547^{* * *} \\
(0.558) \\
\end{array}$ & $\begin{array}{c}-14.110^{* * *} \\
(1.762) \\
\end{array}$ & $\begin{array}{c}12.923^{* * *} \\
(2.033) \\
\end{array}$ \\
\hline Wald test & $\begin{array}{c}10411.45 \\
(0.000) \\
\end{array}$ & $\begin{array}{c}15281.04 \\
(0.000) \\
\end{array}$ & $\begin{array}{c}2540.84 \\
(0.000) \\
\end{array}$ & $\begin{array}{c}4436.52 \\
(0.000) \\
\end{array}$ & $\begin{array}{c}6827.50 \\
(0.000) \\
\end{array}$ & $\begin{array}{c}4037.67 \\
(0.000) \\
\end{array}$ & $\begin{array}{c}9879.36 \\
(0.000) \\
\end{array}$ \\
\hline $\begin{array}{l}\operatorname{AR}(1) \\
\mathrm{AR}(2)\end{array}$ & $\begin{array}{l}0.036 \\
0.949\end{array}$ & $\begin{array}{l}0.026 \\
0.958\end{array}$ & $\begin{array}{l}0.031 \\
0.890\end{array}$ & $\begin{array}{l}0.043 \\
0.766\end{array}$ & $\begin{array}{l}0.038 \\
0.920\end{array}$ & $\begin{array}{l}0.044 \\
0.921\end{array}$ & $\begin{array}{l}0.036 \\
0.851\end{array}$ \\
\hline Sargan test & $\begin{array}{l}26.671 \\
(0.997) \\
\end{array}$ & $\begin{array}{l}23.363 \\
(1.000) \\
\end{array}$ & $\begin{array}{l}23.754 \\
(1.000) \\
\end{array}$ & $\begin{array}{l}25.186 \\
(1.000)\end{array}$ & $\begin{array}{l}24.323 \\
(1.000) \\
\end{array}$ & $\begin{array}{l}24.163 \\
(1.000) \\
\end{array}$ & $\begin{array}{l}22.393 \\
(1.000)\end{array}$ \\
\hline
\end{tabular}

Notes: (1) Wald test, AR (1), AR (2), and Sargan test provide the $P$ value of the test, respectively. (2) L1 represents the lagging period of the variable. * , **, and ${ }_{* * *}$ indicate that the coefficients are statistically significant at $10 \%, 5 \%$, and $1 \%$ levels, respectively.

TABLe 7: Robust test.

\begin{tabular}{|c|c|c|c|c|}
\hline & \multicolumn{2}{|c|}{ Static panel } & \multicolumn{2}{|c|}{ Dynamic panel } \\
\hline & Pool OLS & Panel FE & DIF-GMM & SYS-GMM \\
\hline$L_{1} \cdot \ln R I$ & & & $0.386^{* * *}(0.037)$ & $0.325^{* * *}(0.042)$ \\
\hline $\ln M I$ & $0.425^{* * *}(0.139)$ & $0.296^{*}(0.150)$ & $0.175^{* *}(0.175)$ & $0.126^{* *}(0.058)$ \\
\hline $\operatorname{lnGOV}$ & $0.260^{* *}(0.102)$ & $0.113(0.166)$ & $0.111^{* *}(0.052)$ & $0.329(0.259)$ \\
\hline $\ln \mathrm{PTI}$ & $-0.523^{*}(0.279)$ & $-0.230(0.393)$ & $-0.093(0.211)$ & $0.266(0.305)$ \\
\hline $\operatorname{lnINT}$ & $0.510^{* * *}(0.065)$ & $0.658^{* * *}(0.116)$ & $0.261^{* * *}(0.035)$ & $0.151^{* * *}(0.050)$ \\
\hline $\operatorname{lnFDI}$ & $-0.026(0.052)$ & $-0.029(0.091)$ & $0.201^{* * *}(0.030)$ & $0.069^{*}(0.038)$ \\
\hline $\operatorname{lnGDP}$ & $1.143^{* * *}(0.108)$ & $1.210(0.269)$ & $0.218^{* *}(0.089)$ & $0.633^{* * *}(0.087)$ \\
\hline $\ln \mathrm{TR}$ & $0.491^{* * *}(0.087)$ & $0.026(0.269)$ & $0.355^{* * *}(0.117)$ & $0.063(0.164)$ \\
\hline Cons & $-22.157^{* * *}(1.315)$ & $-22.781^{* * *}(3.077)$ & $-7.960^{* * *}(1.368)$ & $-13.385^{* * *}(1.484)$ \\
\hline$R^{2}$ & 0.732 & 0.689 & & \\
\hline Wald test & & & $\begin{array}{c}5705.01 \\
(0.000)\end{array}$ & $\begin{array}{c}2241.74 \\
(0.000)\end{array}$ \\
\hline $\operatorname{AR}(1)$ & & & 0.078 & 0.064 \\
\hline $\operatorname{AR}(2)$ & & & 0.860 & 0.870 \\
\hline Sargan test & & & $\begin{array}{l}25.911 \\
(0.209)\end{array}$ & $\begin{array}{l}25.772 \\
(1.000)\end{array}$ \\
\hline
\end{tabular}

${ }^{*},{ }^{* *}$, and ${ }^{* * *}$ indicate that the coefficients are statistically significant at $10 \%, 5 \%$, and $1 \%$ levels, respectively.

Since a static panel model may have missing variables and endogeneity problems, we primarily analyze the estimation results of a dynamic model. The first-order lag term of RI is added to the dynamic panel model. The results of dynamic panel DIF-GMM and SYS-GMM show that the first-order lag term of RI is significantly positive, indicating that RI has a certain path dependence. RI is a long-term process, and the previous RI will affect the current RI.

In DIF-GMM and SYS-GMM, it can be seen from Models 1-7 that, after adding the control variables, the estimated coefficients of MI of core explanatory variables are significantly positive and the size of the coefficients changes little, indicating that the estimation results are relatively stable. MI has a positive impact on RI and promoting MI can be another driving force of RI. As mentioned above, the estimation efficiency of SYS-GMM is higher than that of DIF-GMM [33]. Therefore, the following analysis focuses on the results of SYS-GMM estimation.

The results of the SYS-GMM estimation show that the coefficient of government support is significantly positive, indicating that government support for scientific and technological innovation has promoted the development of RI. The coefficient of the tertiary industry is significantly positive, indicating that the development of the tertiary 
industry, especially "new infrastructure" industries, is conducive to RI among cities. The information coefficient is remarkable. The development of the Internet facilitates the transmission of information, boosts technological progress, and promotes RI. The coefficient of foreign trade dependence on RI is significantly positive, which shows that the use of foreign capital can introduce advanced foreign technology and boost domestic technological progress. The coefficient of transportation infrastructure is significantly positive, indicating that transportation infrastructure speeds up the narrowing of the distance between cities, which is conducive not only to urban integration but also to technological exchange, cooperation, and intercity innovation.

\section{Robustness Check}

There are two kinds of patent authorization and acceptance. Therefore, to further test the robustness of the conclusion, this paper uses city per capita patent authorization to replace the original dependent variable to measure RI and tests whether the relationship between MI and RI is still valid. At the same time, the static panel model and dynamic panel model are constructed, and the dynamic panel model is estimated by DIF-GMM and SYS-GMM. The results are shown in Table 7.

After considering the dynamic effects and possible missing variables, the results of dynamic panel DIF-GMM and SYS-GMM show that the impact of MI on RI is significantly positive and the model passes the series correlation test and the Sargan test, which shows that the two kinds of GMM estimation results are consistent and effective. When the original dependent variable is replaced by the number of patent grants per capita, the regression result is basically consistent with the above; in other words, the impact of MI on RI is significantly positive, indicating that the conclusion is robust.

\section{Conclusions and Policy Recommendations}

The question of whether MI can affect RI has lacked attention. Using the panel data of 27 cities in the YRD region in China with the highest degree of economic integration from 2009 to 2018, the "price index method" is used to measure the MI index. On this basis, static and dynamic panel models DIF-GMM and SYS-GMM are constructed to investigate the impact of MI on RI. The main findings are as follows: the first-order lag term of RI is significantly positive, and RI has a certain path dependence. MI has a positive impact on RI and promotes RI. Moreover, the results are robust after adopting different RI indicators and considering the endogeneity problems that may exist in the model. This conclusion provides a reference for promoting RI through regional integration. The results of the SYS-GMM estimation show that the coefficient of government support is significantly positive, indicating that government support for scientific and technological innovation has promoted the development of RI. The coefficient of the tertiary industry is significantly positive, indicating that the development of the tertiary industry, especially "new infrastructure" industries, is conducive to RI among cities. The information coefficient is remarkable. The development of the Internet facilitates the transmission of information, boosts technological progress, and promotes RI. The coefficient of foreign trade dependence on RI is significantly positive, which shows that the use of foreign capital can introduce advanced foreign technology and boost domestic technological progress. The coefficient of transportation infrastructure is significantly positive and transportation infrastructure speeds up the narrowing of the distance between cities, which is conducive not only to urban integration but also to technological exchange, cooperation, and intercity innovation.

The policy implications of these conclusions are as follows. First, the government should further promote the YRD MI process. The MI of the YRD can not only promote economic development through free flow of factors and optimal allocation of resources but also strengthen RI to a certain extent. Therefore, local governments in the YRD should be open-minded and strengthen mutual exchanges and cooperation. The central government can bring the MI index of the cities in the YRD into the assessment scope, guide the YRD to strengthen cooperation, and improve the depth and breadth of MI in the YRD. To promote the market integration of the YRD, the government should guide its cities to strengthen cooperation and improve the depth and breadth of the regional integration. The YRD should establish a new pattern of RI by strengthening technical exchanges and cooperation. Technology, knowledge, and information are highly mobile. Strengthening cooperation between cities will enhance the enthusiasm of local enterprises for innovation and promote technological progress. Therefore, cities in the YRD should strengthen their own innovation capabilities while also using MI to build crossregional technology, knowledge, and other trading markets and strengthen technological innovation and cooperation between cross-regional enterprises. Concurrently, it is necessary to build a technical cooperation platform for cross-regional universities, scientific research institutions, and enterprise R\&D departments to promote the cross-regional integration of industry, education, and research.

Second, governments in the YRD should increase their support for scientific and technological innovation. Therefore, local governments at all levels in the YRD should increase their financial investments in science and technology, optimize the technological innovation environment, attract the inflow of $\mathrm{R} \& \mathrm{D}$ talent, equipment, and other factors, and improve innovation levels by increasing stock. Local governments can focus on supporting key areas and linkages, such as integrated circuits biomedical and artificial intelligence, and strive to make substantive breakthroughs in these areas as soon as possible. In addition, we should improve the efficiency of the transformation of scientific and technological achievements. We should support the innovation and development of small and medium-sized microtechnology enterprises.

Third, we should vigorously develop the tertiary industry. The coefficient of the tertiary industry is significantly positive and the development of the tertiary industry is conducive to regional innovation between cities. The 
technology industry itself belongs to the tertiary industry and promoting it will, in turn, develop the tertiary industry as a whole. In addition, the development of financial and other services in the tertiary industry can provide financial support for technological innovation. The development and growth of the tertiary industry, while also fueling economic development, will feed back technological innovation and provide material support for technological innovation. Therefore, the YRD region should optimize its economic structure, reduce the proportion of primary and secondary industries, and expand the proportion of tertiary industry to promote technological innovation.

Fourth, we should promote the process of informatization. With the rapid development of information technology in China's vast cities as of December 2020, China's Internet users reached 989 million, an increase of 85.4 million compared with March 2020, and the Internet penetration rate reached $70.4 \%$. The Internet penetration rate of the YRD is among the highest in China. At present, the YRD should further promote the informatization process and develop new infrastructure, including the new generation of information networks, particularly the development of 5G applications. At the same time, the construction of charging piles should be strengthened to promote the informatization process of the YRD.

Fifth, we should actively utilize foreign capital. Using foreign capital can introduce advanced foreign technology and boost domestic technological progress. The YRD can introduce high-tech products, increase the proportion of investment in high-tech industries, improve the quality of foreign capital utilization, and deeply integrate itself into the global innovation network system.

Finally, we should strengthen the construction of transportation infrastructure. The development goal of the YRD transportation higher-quality integrated development plan is "by 2025, focusing on the integrated development, and on the basis of accurately completing the short board of development, speed up the construction of the YRD modern comprehensive transportation system." Therefore, the YRD should strengthen transportation interconnectedness and build high-quality trunk railways, intercity railways, urban (suburban) railways, and rail transit. Modern and interconnected transportation networks will promote the integration of the YRD.

\section{Data Availability}

The data used to support the findings of this study are available from the corresponding author upon request.

\section{Conflicts of Interest}

The author declares that they have no conflicts of interest.

\section{Acknowledgments}

This research was sponsored by the Philosophy and Society Project of Universities in Jiangsu Province (2020SJA0492).

\section{References}

[1] B. Hoekman and A. Nicita, "Trade policy, trade costs, and developing country trade," World Development, vol. 39, no. 12, pp. 2069-2079, 2011.

[2] S. Ke, "Domestic market integration and regional economic growth-China's recent experience from 1995-2011," World Development, vol. 66, pp. 588-597, 2015.

[3] A. Young, "The razor's edge: distortions and incremental reform in the People's Republic of China quarterly," Quarterly Journal of Economics, vol. 115, no. 4, pp. 1091-1135, 2000.

[4] S. Poncet, "Measuring Chinese domestic and international integration," China Economic Review, vol. 14, no. 1, pp. 1-21, 2003.

[5] B. Naughton, "How much can regional integration do to unify China's markets," in Proceedings of the Conference for Research on Economic Development and Policy Research Stanford University, Stanford, CA, USA, August 1999.

[6] X. Xu, "Have the Chinese provinces become integrated under reform?" China Economic Review, vol. 13, no. 2, pp. 116-133, 2002.

[7] M. Hellwig, D. Schober, and O. Woll, "Measuring market integration and estimating policy impacts on the Swiss electricity market," Energy Economics, vol. 86, Article ID 104637, 2020.

[8] K. P. Gluschenko, "Long-term evolution of Russia's market integration," Studies on Russian Economic Development, vol. 32, no. 1, pp. 78-86, 2021.

[9] J. Li and B. Lin, "Does energy and $\mathrm{CO} 2$ emissions performance of China benefit from regional integration?" Energy Policy, vol. 101, pp. 366-378, 2017.

[10] W. He, B. Wang, and Z. Wang, "Will regional economic integration influence carbon dioxide marginal abatement costs? evidence from Chinese panel data," Energy Economics, vol. 74, pp. 263-274, 2018.

[11] S. Shao, Y. Chen, K. Li, and L. Yang, "Market segmentation and urban $\mathrm{CO} 2$ emissions in China: evidence from the Yangtze River Delta region," Journal of Environmental Management, vol. 248, Article ID 109324, 2019.

[12] K. Zhang, "Is regional integration beneficial to emissions reduction?" Journal of Financial Research, vol. 451, no. 1, pp. 67-83, 2018.

[13] J.-L. Duanmu, M. Bu, and R. Pittman, "Does market competition dampen environmental performance? Evidence from China," Strategic Management Journal, vol. 39, no. 11, pp. 3006-3030, 2018.

[14] J. Bai, J. Lu, and S. Li, "Fiscal pressure, tax competition and environmental pollution," Environmental and Resource Economics, vol. 73, no. 2, pp. 431-447, 2018.

[15] Y. Bian, K. Song, and J. Bai, "Market segmentation, resource misallocation and environmental pollution," Journal of Cleaner Production, vol. 228, pp. 376-387, 2019.

[16] J. M. Uribe, S. Mosquera-López, and M. Guillen, "Characterizing electricity market integration in Nord Pool," Energy, vol. 208, Article ID 118368, 2020.

[17] K. Zhang, S. Shao, and S. Fan, "Market integration and environmental quality: evidence from the Yangtze river delta region of China," Journal of Environmental Management, vol. 261, Article ID 110208, 2020.

[18] H. Su and B. Liang, "The impact of regional market integration and economic opening up on environmental total factor energy productivity in Chinese provinces," Energy Policy, vol. 148, Article ID 111943, 2021. 
[19] S. Hou and L. Song, "Market integration and regional green total factor productivity: evidence from China's provincelevel data," Sustainability, vol. 13, no. 2, Article ID 472, 2021.

[20] A. Hu and G. F. D. I. Jefferson, Technological Innovation and Spillover: Evidence from Largeand Medium Size Chinese Enterprises Waltham, Brandeis University, MA, USA, 2001.

[21] S. Barrios, H. Görg, and E. Strobl, "Foreign direct investment, competition and industrial development in the host country," European Economic Review, vol. 49, no. 7, pp. 1761-1784, 2005.

[22] A. Young, "Substitution and complementarity in endogenous innovation," Quarterly Journal of Economics, vol. 108, no. 3, pp. 775-807, 1993.

[23] G. Federico, "Market integration and market efficiency: the case of 19th Century Italy," Explorations in Economic History, vol. 44, no. 2, pp. 293-316, 2007.

[24] X. Sun, X. Zhou, Z. Chen, and Y. Yang, "Environmental efficiency of electric power industry, market segmentation and technological innovation: empirical evidence from China," The Science of the Total Environment, vol. 706, Article ID 135749, 2020.

[25] M. Arellano and S. Bond, "Some tests of specification for panel data: Monte Carlo evidence and an application to employment equations," The Review of Economic Studies, vol. 58, no. 2, pp. 277-297, 1991.

[26] R. Blundell and S. Bond, "Initial conditions and moment restrictions in dynamic panel data models," Journal of Econometrics, vol. 87, no. 1, pp. 115-143, 1998.

[27] D. Roodman, "How to do xtabond2: an introduction to difference and system GMM in Stata," STATA Journal: Promoting communications on statistics and Stata, vol. 9, no. 1, pp. 86-136, 2009.

[28] D. Parsley and S. Wei, Limiting Currency Volatility to Stimulate Goods Market Integration: A Price Based Approach, National Bureau of Economic Research Working Paper Series No. 8468, Cambridge, MA, USA, 2001.

[29] K. Luo, G. Li, C. Fang, and S. Sun, "PM2.5 mitigation in China: socioeconomic determinants of concentrations and differential control policies," Journal of Environmental Management, vol. 213, pp. 47-55, 2018.

[30] K. Zaman and M. A.-e. Moemen, "Energy consumption, carbon dioxide emissions and economic development: evaluating alternative and plausible environmental hypothesis for sustainable growth," Renewable and Sustainable Energy Reviews, vol. 74, pp. 1119-1130, 2017.

[31] W. Cao, H. Wang, and H. Ying, "The effect of environmental regulation on employment in resource-based areas of Chinaan empirical research based on the mediating effect model," International Journal of Environmental Research and Public Health, vol. 14, no. 12, Article ID 1598, 2017.

[32] J. D. Sargan, "The estimation of economic relationships using instrumental variables," Econometrica, vol. 26, no. 3, pp. 393-415, 1958.

[33] F. Halicioglu and N. Ketenci, "The impact of international trade on environmental quality: the case of transition countries," Energy, vol. 109, pp. 1130-1138, 2016. 